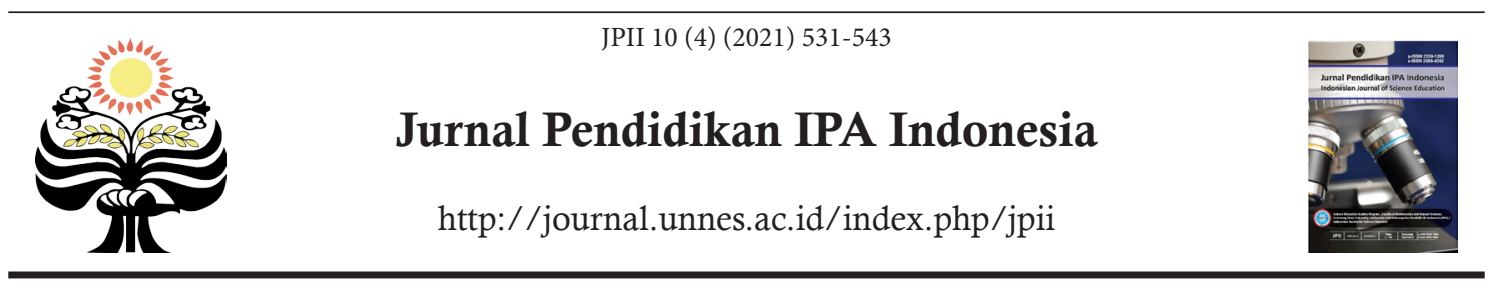

\title{
THE ASSESSMENT OF WATER COMPATIBILITY OF ADAPTABLE STICK-NET CAGE FOR RESILIENCE MILKFISH CULTIVATION IN TANJUNG MAS, INDONESIA
}

\author{
N. K. T Martuti*1 , W. A. B. N. Sidiq ${ }^{2}$, I. S. Melati ${ }^{3}$, D. P. Mutiatari ${ }^{4}$ \\ ${ }^{1}$ Biology Department, Faculty of Mathematics and Natural Sciences, Universitas Negeri Semarang, Indonesia \\ ${ }^{2}$ Geography Department, Faculty of Social Sciences, Universitas Negeri Semarang, Indonesia \\ ${ }^{3}$ Economy Department, Faculty of Economy, Universitas Negeri Semarang, Indonesia \\ ${ }^{4}$ Study Center of Community Services and Empowerment, Research and Community Services Institution of \\ Universitas Negeri Semarang, Indonesia
}

DOI: 10.15294/jpii.v10i4.32174

Accepted: September $26^{\text {th }} 2021$. Approved: December $27^{\text {th }} 2021$. Published: December $31^{\text {st }} 2021$

\begin{abstract}
Milkfish cultivation becomes the main livelihood of farmers in coastal areas. However, the land for milkfish cultivation is shrinking due to land use for settlements, industries, and sea-level rise. A Stick-net cage is an aquaculture solution in limited space for an inland fishpond. It can be placed in seashore areas while maintaining the quality of the aquatic environment and nutrient circulation. This study aims to analyze water compatibility in the stick-net cage areas for supporting sustainable aquaculture activities. An exploratory observational study was conducted in Tanjung Mas Village, Semarang, Central Java, Indonesia. Ten sampling areas were determined purposively by considering the point locations toward household wastewater and industrial outfalls. Based on these criteria, the ten stations used as sample areas were divided into industrial outfall areas $\left(1^{\text {st }}-5^{\text {th }}\right.$ station) and areas close to the open sea $\left(6^{\text {th }}-10^{\text {th }}\right.$ station). Physical parameters in the sampling areas, including temperature, water-current, turbidity, and clearness, met seawater standards for milkfish cultivation. Chemical indicators, such as $\mathrm{NH}_{4}$ and $\mathrm{P}$ in water, were very high, which may be caused by domestic and industrial waste contamination and increased organic fermentation activity on the seabed. However, the existing stick-net cages have exceeded the capacity of the coastal water areas. In general, the physicochemical parameters in the Tanjung Mas water area are suitable for milkfish cultivation. However, it is necessary to reduce the amount of pond density to give growth space for milkfish. In addition, wastewater management and treatment plants should be built up to reduce water contamination.
\end{abstract}

(C) 2021 Science Education Study Program FMIPA UNNES Semarang

Keywords: coastal management; sustainable livelihood; water compatibility

\section{INTRODUCTION}

Semarang is a coastal city that produces milkfish in Central Java, with 328.65 tons in 2020. Milkfish is the main cultivated fish commodity in Semarang and the livelihood for more than 1500 pond farmers with a total income of 6.32 trillion per year (Central Java Statistics Agency [BPS], 2021). One area in Semarang that relies on milkfish cultivation as its primary income source is

*Correspondence Address

E-mail: nanakariada@mail.unnes.ac.id the fish-farmer community in Tanjung Mas. Inland pond for milkfish cultivation is at risk of being damaged by high waves and sea-level rise as the effect of climate change (Ahmed et al., 2019). In-land milkfish cultivation is practiced on community land, in coastal areas that are insulated by soil-embankment planted with mangroves. The depth of fishponds ranges from one to three meters, so dredging must continue due to sedimentation. The quality of the inland pond water is strongly influenced by fresh-water circulation and river flow. Over the last ten years, abrasion 
has caused a shift in the coastline in Semarang by more than $0.5 \mathrm{~km}$ (Irsadi et al., 2019) and the loss of ponds in coastal areas (Andreas et al., 2018). In addition, the increase of industry, housing, and commercial spaces have decreased pond cultivation areas in Semarang. As a result, milkfish farmers experience a decline in milkfish production, threatening business stability (Martuti et al., 2020) and lowering resilience against climate change (Bosma et al., 2017; Purwaningsih \& Hermawan, 2021), land-use conflicts, and potential threats from anthropogenic factors, including industrial and household waste (Henriksson et al., 2019). A case study in the Tanjung Mas water area shows that the high-risk milkfish cultivation due to climate change and land-use conflict has prompted milkfish farmers to change to using cages planted in coastal waters.

An adaptation activity in milkfish cultivation has been initiated by farmers in Tanjung Mas, Semarang, who take initiation to build stick-net cages (Keramba Jaring Tancap [KJT]) in shallow water areas. KJT is arranged using bamboo sticks stuck to the seabed and installed with the net on the edges to the bottom. Furthermore, KJT is a community adaptation product in facing climate change which reduces their income. However, this solution is developed more based on the large profits obtained from aquaculture but ignoring environmental sustainability. Even though, this cultivation technique is claimed to be able to maintain water quality, nutrient circulation, and physical conditions to support milkfish growth (Sambu, 2017). Therefore, a study on the importance of assessing the environmental conditions and the effect of KJT on water bodies needs to be conducted.

An assessment about environmental sustainability and the effect of KJT in the Tanjung Mas water area is rarity conducted, whereas the delta area in that area becomes an outlet for domestic and industrial waste. The waste pollution may interfere with milkfish growth during cultivation. Furthermore, technology transformation from inland milkfish cultivation to KJT needs to be studied in-depth, especially the factors affecting pond water quality (Ganesh et al., 2020). In addition, chemical and organic contamination may increase in the estuarine ecosystem that affects fish growth because of replaced cultivation activity. In recent studies, the anthropogenic fac- tors, such as chemical pesticides, drugs (Chang et al., 2019), and feed (Srithongouthai \& Tada, 2017) in milkfish cultivation affects the physicochemical conditions of the aquatic ecosystem.

Inland aquaculture practice currently ignores the carrying capacity of the aquatic environment, which causes a decline in the estuary ecosystem quality (Gusmawati et al., 2018; Proisy et al., 2018; Hukom et al., 2020). Hence, aquaculture management strategies using KJT must be conducted in line with the principle of sustainable development through balancing the social aspects, economic resources management, and environmental sustainability (Boyd et al., 2020). Therefore, this study aims to analyze the suitability of water conditions and biophysical aspects to support sustainable aquaculture activities in the Tanjung Mas coastal area. This study is expected to raise awareness among aquaculture actors regarding the suitability of the coastal area in their territory.

\section{METHODS}

This research was an explorational observation conducted in the KJT aquaculture area, administratively included in the Tanjung Mas, Semarang, Central Java, Indonesia. Data were taken in June - August or during the dry season to photograph the pond water original condition accurately. Sampling was carried out at 10 points spread from the end of the Mati River to the vicinity of the KJT location at the river's delta. The sample point was determined purposively by considering 1) the location of household wastewater discharge, the outfall of industries around the river, and the site of the KJT. Based on these criteria, the 10 sample area points were divided into 1) industrial waste and outfall areas (points $1-5)$, as assumed that the waters are directly contaminated by sewage, and 2) the areas close to the open sea (points 6-10), as assumed that the open sea has a mechanism to eliminate the waste as an effect of the ocean currents (Figure 1). Water samples were collected compositely from the pond area by taking $1 \mathrm{~L}$ of water each from five points or sides and the pond center. The water was then combined and homogenized before being used for further analysis. The water samples are stored in dark bottles to avoid chemical damage and physical changes due to light. 


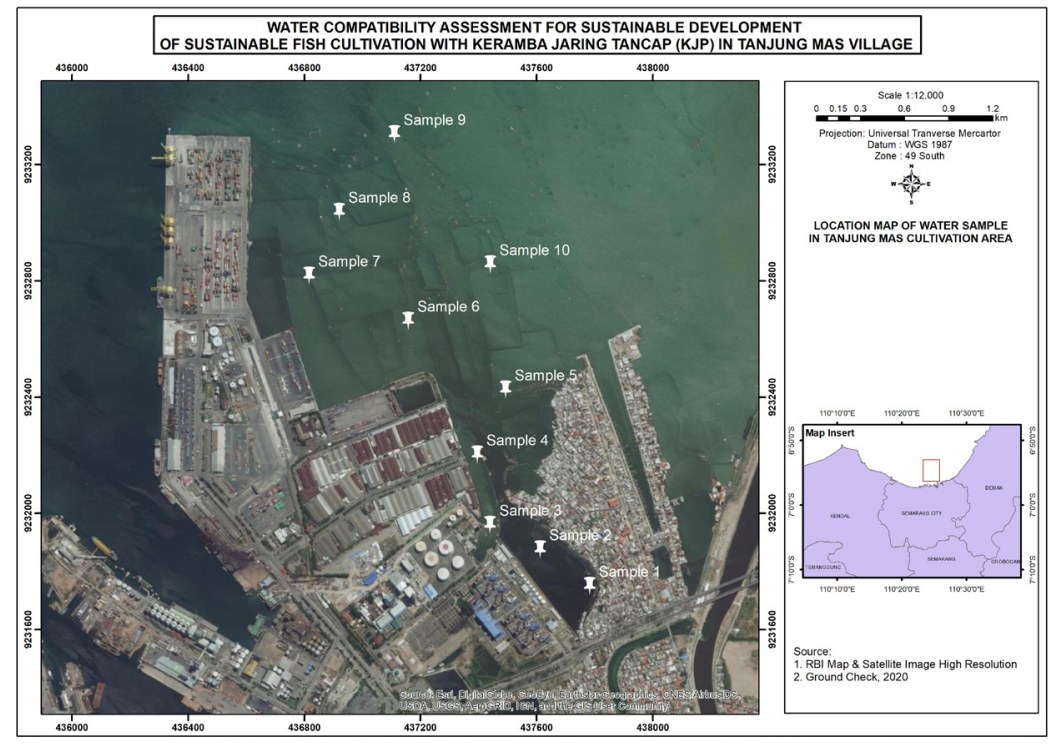

Figure 1. Map of the Location for Determining the Water Suitability Analysis Sample

Data on water conditions that support milkfish cultivation in this study were grouped into two parameters, physical and chemical (Table 1). The parameters were selected from the Go- vernment Regulation (PP) No. 22 of 2021 about seawater quality standards for cultivation (Table 1).

Table 1. Water Suitability Analysis (Site Capability)

\begin{tabular}{|c|c|c|c|c|}
\hline $\begin{array}{l}\text { Physicochemical } \\
\text { Parameters (n) }\end{array}$ & Scoring Assumption and Instrument & $\begin{array}{l}\text { Parameter } \\
\text { Values } \\
\left(\mathbf{S}_{\mathrm{n}}\right)\end{array}$ & $\begin{array}{l}\text { Rubric } \\
\text { Score }^{* *}\end{array}$ & $\begin{array}{l}\text { Weight } \\
\text { (W) }\end{array}$ \\
\hline \multirow[t]{4}{*}{ Seawater depth $(\mathrm{m})$} & \multirow{3}{*}{$\begin{array}{l}\text { Sea depths between } 0-10 \text { provide circula- } \\
\text { tion of nutrients and plankton needed for } \\
\text { fish growth }\end{array}$} & $\leq 5$ & 5 & 3 \\
\hline & & $5-10$ & 3 & \\
\hline & & $\geq 10$ & 1 & \\
\hline & Measurement tool: roller metline, in situ & & & \\
\hline \multirow{3}{*}{$\begin{array}{l}\text { Light penetration } \\
(\mathrm{cm})\end{array}$} & \multirow{2}{*}{$\begin{array}{l}\text { Minimum light penetration for milkfish } \\
\text { cultivation ranges from } 30-40 \mathrm{~cm} \text {. }\end{array}$} & $\leq 3$ & 5 & 1 \\
\hline & & $3-5$ & 3 & \\
\hline & Measurement tool: Secchi disk & $\geq 5$ & 1 & \\
\hline \multirow[t]{4}{*}{ Turbidity (NTU) } & \multirow{3}{*}{$\begin{array}{l}\text { Turbidity is related to the penetration of } \\
\text { light needed by phytoplankton for photo- } \\
\text { synthesis. A reasonable water threshold is } \\
<5 \text {. }\end{array}$} & $\leq 5$ & 5 & 1 \\
\hline & & $>5-20$ & 3 & \\
\hline & & $>20$ & 1 & \\
\hline & $\begin{array}{l}\text { Measurement tool: multiparameter water } \\
\text { quality analyzer, in situ }\end{array}$ & & & \\
\hline \multirow[t]{3}{*}{ Water current $(\mathrm{m} / \mathrm{s})$} & \multirow{2}{*}{$\begin{array}{l}\text { Current plays a role in water circulation, } \\
\text { which affects the amount of dissolved } \\
\text { oxygen and nutrients in the water. }\end{array}$} & $20-40$ & 5 & 3 \\
\hline & & $\begin{array}{c}10-<20 \text { or }> \\
40-70\end{array}$ & 3 & \\
\hline & Measurement tool: water current meter & $<10$ or $>70$ & 1 & \\
\hline \multirow[t]{3}{*}{ Temperature (C) } & \multirow{2}{*}{$\begin{array}{l}\text { The optimum temperature for milkfish } \\
\text { growth is between } 23^{\circ} \mathrm{C}-35^{\circ} \mathrm{C} \text {. Water } \\
\text { temperature affects the growth and devel- } \\
\text { opment of milkfish. }\end{array}$} & $28-30$ & 5 & 2 \\
\hline & & $\begin{array}{c}26-<28 \text { or } \\
>30-31\end{array}$ & 3 & \\
\hline & $\begin{array}{l}\text { Measurement tool: multiparameter water } \\
\text { quality analyzer, in situ }\end{array}$ & $<26$ or $>31$ & 1 & \\
\hline
\end{tabular}




\begin{tabular}{|c|c|c|c|c|}
\hline $\begin{array}{l}\text { Physicochemical } \\
\text { Parameters (n) }\end{array}$ & Scoring Assumption and Instrument & $\begin{array}{l}\text { Parameter } \\
\text { Values } \\
\left(\mathbf{S}_{n}\right)\end{array}$ & $\begin{array}{l}\text { Rubric } \\
\text { Score }^{* *}\end{array}$ & $\begin{array}{l}\text { Weight } \\
\text { (W) }\end{array}$ \\
\hline \multirow[t]{3}{*}{$\mathrm{DO}(\mathrm{mg} / \mathrm{l})$} & \multirow{3}{*}{$\begin{array}{l}\text { DO levels suitable for marine life are in the } \\
\text { range of }>5 \mathrm{mg} / \mathrm{L} \text { or } 4-8 \mathrm{ppm} \\
\text { Measurement tool: multiparameter water } \\
\text { quality analyzer, in situ }\end{array}$} & $\geq 5$ & 5 & \multirow[t]{3}{*}{3} \\
\hline & & $\geq 3-<5$ & 3 & \\
\hline & & $<3$ & 1 & \\
\hline \multirow[t]{3}{*}{$\mathrm{pH}$} & \multirow{2}{*}{$\begin{array}{l}\text { A good } \mathrm{pH} \text { value in milkfish cultivation is } \\
\text { between } 6.5-9 \text {. }\end{array}$} & $7.5-8$ & 5 & \multirow[t]{3}{*}{2} \\
\hline & & $\begin{array}{l}7-<7.5 \text { or } \\
>8-8.5\end{array}$ & 3 & \\
\hline & Measurement tool: $\mathrm{pH}$ meter & $<7$ or $>8.5$ & 1 & \\
\hline \multirow[t]{3}{*}{ Salinity (\%) } & \multirow{2}{*}{$\begin{array}{l}\text { Good salinity for milkfish cultivation rang- } \\
\text { es from 0-35. }\end{array}$} & $29-31$ & 5 & \multirow[t]{3}{*}{2} \\
\hline & & $\begin{array}{c}27-<29 \text { or } \\
>31-33\end{array}$ & 3 & \\
\hline & Measurement tool: refractometer & $<27$ or $>33$ & 1 & \\
\hline \multirow[t]{4}{*}{ Nitrate $(\mathrm{mg} / \mathrm{L})$} & \multirow{4}{*}{$\begin{array}{l}\text { Phytoplankton can grow optimally at a } \\
\text { nitrate content of } 0.9 \pm 3.5 \mathrm{mg} / 1 \text {, while } \\
\text { at concentrations below } 0.01 \text { or above } 4.5 \\
\text { mg/l, it can be a limiting factor for phyto- } \\
\text { plankton growth. } \\
\text { Measurement tool: multiparameter water } \\
\text { quality analyzer, Laboratory analysis }\end{array}$} & $<0.008$ & 5 & \multirow[t]{4}{*}{1} \\
\hline & & $>0.008-0.4$ & 3 & \\
\hline & & $>0.4$ & 1 & \\
\hline & & & & \\
\hline \multirow[t]{3}{*}{ Nitrite (mg/L) } & \multirow{3}{*}{$\begin{array}{l}\text { High nitrite causes a decrease in water } \mathrm{pH} \\
\text { and is toxic to marine biota } \\
\text { Measurement tool: multiparameter water } \\
\text { quality analyzer, Laboratory analysis }\end{array}$} & 0 & 5 & \multirow[t]{3}{*}{1} \\
\hline & & $<0.1$ & 3 & \\
\hline & & $\geq 0.1$ & 1 & \\
\hline \multirow{3}{*}{$\begin{array}{l}\text { Phosphate } \\
(\mathrm{mg} / \mathrm{L})\end{array}$} & \multirow{3}{*}{$\begin{array}{l}\text { It is needed for the growth and metabolism } \\
\text { of phytoplankton and marine organisms. } \\
\text { Measurement tool: multiparameter water } \\
\text { quality analyzer, Laboratory analysis }\end{array}$} & $\leq 0.014$ & 5 & \multirow[t]{3}{*}{2} \\
\hline & & $0.015-\leq 0.8$ & 3 & \\
\hline & & $>0.8$ & 1 & \\
\hline \multirow[t]{4}{*}{ Ammonia (mg/L) } & \multirow{4}{*}{$\begin{array}{l}\text { The lethal concentration (LC50) of am- } \\
\text { monia is } 1.10 \text { to } 22.8 \mathrm{ppm} \text { resulting in } 5 \% \\
\text { mortality and } 20 \% \text { growth reduction for } \\
\text { cultured fish } \\
\text { Measurement tool: multiparameter water } \\
\text { quality analyzer, Laboratory analysis }\end{array}$} & $0-0.2$ & 5 & \multirow[t]{4}{*}{1} \\
\hline & & $>0.2-0.5$ & 3 & \\
\hline & & $>0.5$ & 1 & \\
\hline & & & & \\
\hline \multirow[t]{3}{*}{$\mathrm{BOD}(\mathrm{mg} / \mathrm{L})$} & \multirow{3}{*}{$\begin{array}{l}\text { The level of pollution is categorized low if } \\
\text { the BOD value is } 0-10 \mathrm{mg} / \mathrm{L} \text {, while the } \\
\text { level of pollution is moderate if it is } 10-20 \\
\mathrm{mg} / 1 \text {, and high polluted for }>20 \mathrm{mg} / \mathrm{L} \text {. } \\
\text { Measurement tool: multiparameter water } \\
\text { quality analyzer, Laboratory analysis }\end{array}$} & $\leq 10$ & 5 & \multirow[t]{3}{*}{1} \\
\hline & & $>10-45$ & 3 & \\
\hline & & $>45$ & 1 & \\
\hline \multirow[t]{3}{*}{ Seabed materials } & \multirow{3}{*}{$\begin{array}{l}\text { The media affect the survival of milkfish; } \\
\text { thus it affects the success of the enlarge- } \\
\text { ment business. } \\
\text { Measurement tool: Ekman grab, in situ }\end{array}$} & Gravel & 5 & \multirow[t]{3}{*}{2} \\
\hline & & Grit-silt (muddy) & 3 & \\
\hline & & Silt & 1 & \\
\hline
\end{tabular}

Note: * The parameter was adapted Government Regulation (PP) No. 22 of 2021 and modified from Kumar et al. (2017); Olatayo (2014),

$==* *$ Physicochemical parameters that are considered essential and dominant give greater weight in affecting milkfish growth. 
To obtain seawater compatibility value (SC), it was measured from summaries of the weight $(\mathrm{W})$ score that multiplied by the parameter score $\left(\mathrm{S}_{\mathrm{n}}\right)$ for each parameter $(\mathrm{n})$ (Equation 1). The seawater compatibility interval class (Table 2).

$$
\mathrm{SC}=\sum\left(\mathrm{S}_{n} \times \mathrm{W}\right)
$$

Table 2. Water Suitability Classification Criteria

\begin{tabular}{ccc}
\hline $\begin{array}{c}\text { Status } \\
\text { Code }\end{array}$ & $\begin{array}{c}\text { Scoring } \\
\text { Criteria }\end{array}$ & $\begin{array}{c}\text { Compatibility } \\
\text { Status }\end{array}$ \\
\hline S1 & $>146.7$ & Excellent \\
S2 & $93.3-146.7$ & Proper \\
N & $<93.3$ & Improper \\
\hline
\end{tabular}

\section{RESULTS AND DISCUSSION}

Previously, aquaculture in Tanjung Mas was carried out using inland ponds with embankments directly bordering the sea or other ponds. However, in the early 2000s, this activity began to be abandoned because damaged by abrasion and sea-level rise (Surya et al., 2019). Based on the interview, the KJT system was first developed in Tanjung Mas by local farmers in 2008 as an adaptive strategy against destructed inland cultivation. Currently, most of the farmers conduct aquaculture business as a side job when the fishing season is disturbed by weather. However, because milkfish cultivation profit was higher than catching fish, the KJT system became popular and made the farmers shift their main job as Fishermans on KJT cultivation. KJT is made using bamboos construction that is plugged into a seabed forming a cage block. The nets used by the farmers have hole diameters ranging from 0.5 $\mathrm{cm}-0.5 \mathrm{~cm}$ for nursery and $1 \mathrm{~cm}-1 \mathrm{~cm}$ for enlargement (Figure 2). KJT using three layers of nets surround a 1 ha of fishpond with a depth of $3 \mathrm{~m}$. It takes about five rollers of net sizing $30 \mathrm{mx}$ $5 \mathrm{~m}$. The advantage of using KJT is the capability of the construction model that supports nutrient circulation in the seawater. It makes the availability of natural feed for milkfish and reduces additional fed for cultivation (Cornejo et al., 2020).
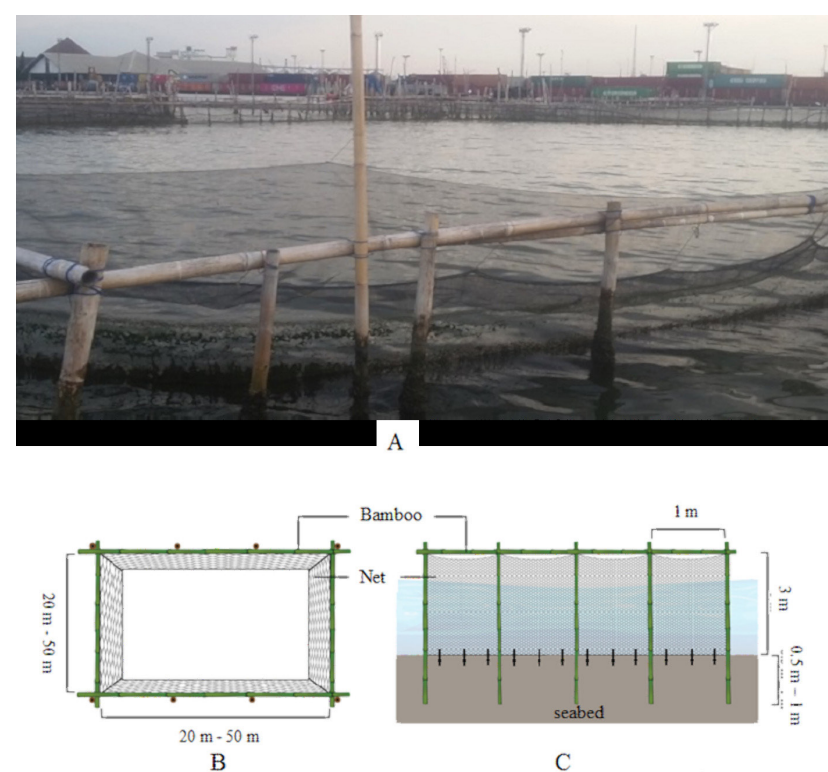

$\mathrm{C}$

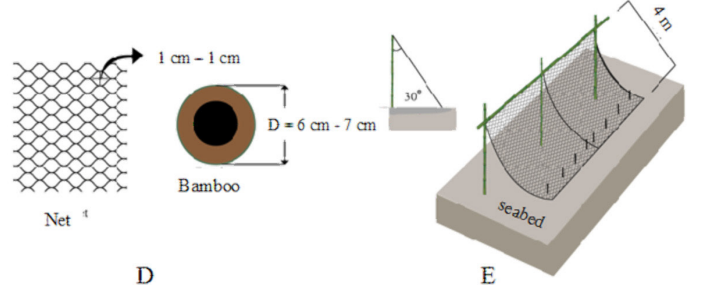

Figure 2. Detailed Design of Stick-net Cage Specification Used for Milkfish Cultivation in Tanjung Mas: A) existing stick-net cage; B) upper view of the net-cage; C) construction design; D) material specification; E) net position on the seabed 
Pollutants from outside and ammonia in the pond, as illustrated in Figure 3 (Cha \& Lee, from feed fermentation inside the cage circulate 2018).

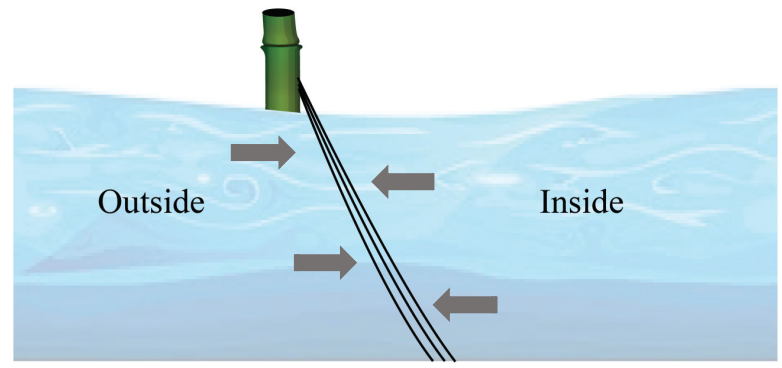

Net

Figure 3. Materials Flow Illustration Through Net-cage Construction

KJT disadvantages are performed by uncontrolled physicochemical conditions inside the cage and are adequately dependent on natural factors. Consequently, the farmers cannot adjust water conditions to speed up milkfish growth. It is necessary to maintain the optimal physical and chemical conditions in the environment according to the age of the milkfish to get optimal growth (Mandal et al., 2018; Failaman et al., 2021).

Seawater aquaculture requires appropriate environmental conditions that support the growth and development of milkfish. In addition, KJT in Tanjung Mas is placed around industrial and household waste streams that contain toxic con-
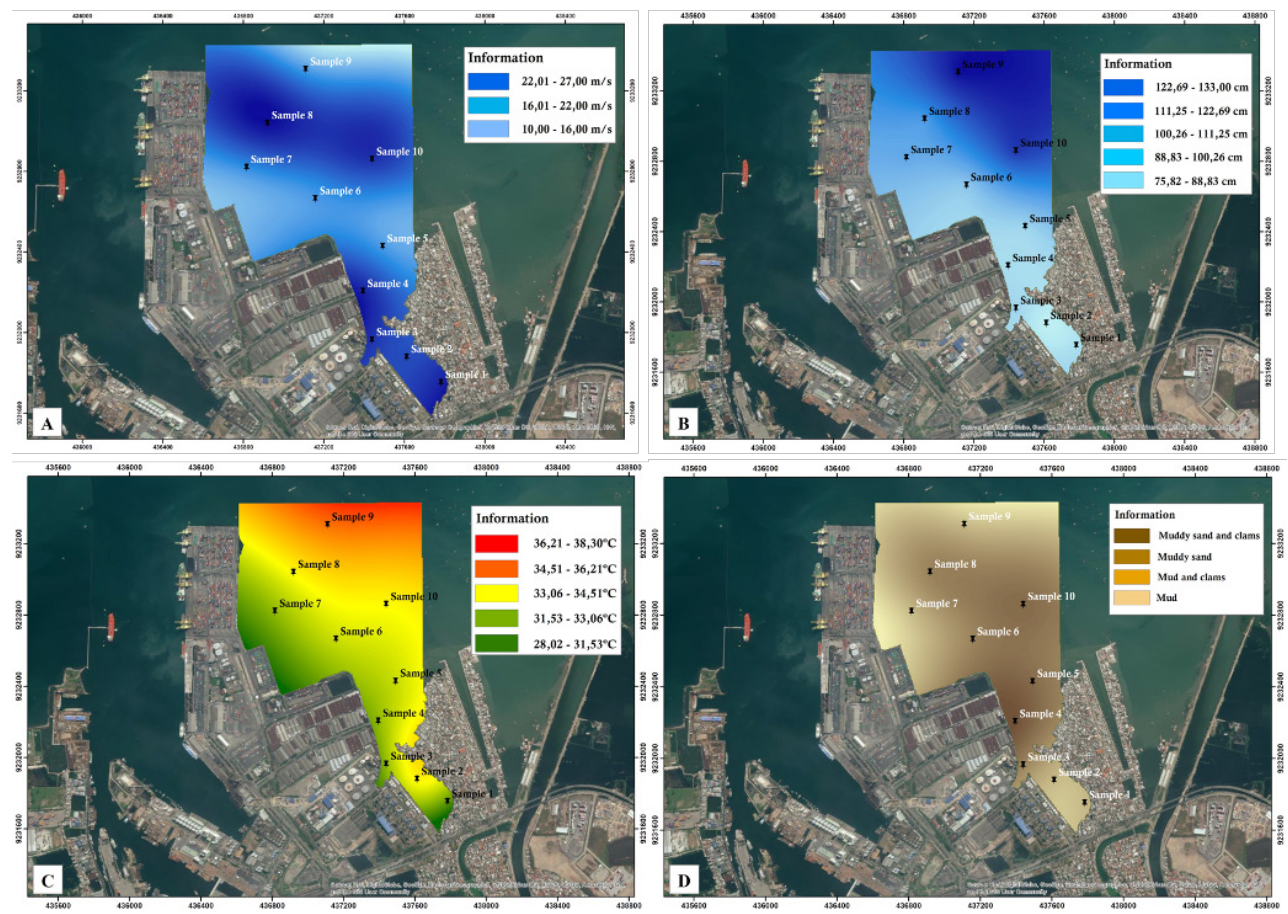

Figure 4. Physical Condition of the Research Sites in Tanjung Mas: A) water current; B) light penetration; C) temperature; D) seabed sediment in Tanjung Mas Fishpond Areas 
The seawater depth varies between $4 \mathrm{~m}-$ $6 \mathrm{~m}$; however, it is still suitable for milkfish cultivation. Milkfish juveniles will generally live in the shallow seawater for two to three weeks, then migrate to mangrove forests, river estuaries, or lakes. The adult will return to the sea to breed. Meanwhile, the substrate samples in Tanjung Mas seawaters range from silt to gravel containing shell fragments and sand. However, the seabed substrate does not directly affect the milkfish growth because the KJT system is placed on the open seas with nets to a maximum depth of $3 \mathrm{~m}$ (field observation). This is in contrast to the inland ponds in the Semarang coastal area, which only have a depth from $1 \mathrm{~m}$ up to $1.5 \mathrm{~m}$ that makes milkfish directly in contact with the bottom substrate of the seawaters.

Light penetration of water brightness (low debris) indicates good conditions to support milkfish cultivation, even though it is in the industrial and household waste disposal system. The light penetration significantly correlates to the photosynthesis rate of phytoplankton in providing natural feed for milkfish growth. The abundance of phytoplankton is also supported by relatively low water current and calming waves that keep the water clear from seabed substrate. The seawater current speed in Tanjung Mas ranges around $10 \mathrm{~m} / \mathrm{s}-25 \mathrm{~m} / \mathrm{s}$ and is categorized as low water flow. The coastal area in Tanjung Mas is an estuary of the Mati River that has a low discharge because the water sources only come from city drainage and water polder. Water current plays a vital role in nutrient circulation, carrying dissolved and suspended materials, feed distribution, total oxygen solubility, and salinity. Tanjung Mas has seawater with a salinity level of $30 \%-34 \%$, which supports milkfish cultivation. Salinity conditions in Tanjung Mas are not much different from the average salinity value of Indonesian waters ranging from $32 \%$ - 34\%o (Hu et al., 2019). Fluctuations in salinity levels are caused by the high evaporation rate of the surface waters in the east monsoon and rainfall, especially in the west monsoon season (Ratnawati et al., 2018) and the discharge of river water that enters the ocean (Hamzah et al., 2020). Their statement is in line with this research that the first observation stati- on has a lower salinity because it is located in the delta flow of the Mati River.

The water temperature of the KJT location in Tanjung Mas ranges between $31^{\circ} \mathrm{C}-37^{\circ} \mathrm{C}$. This temperature is not suitable for milkfish cultivation because the optimal temperature for milkfish growth goes from $27^{\circ} \mathrm{C}-30^{\circ} \mathrm{C}$ (Astuti \& Warsa, 2020). The high temperature in the KJT areas may be influenced by the long dry season that increases the water surface temperature due to the high intensity of sunlight. Temperatures that are too high or too low directly affect milkfish foraging behavior, reduce sensitivity and inhibit juvenile growth (Hanke et al., 2019; Failaman et al., 2021). An increase in temperature raises the decomposition and fermentation of organic matter, producing ammonia that is toxic to fish. The temperature rise also causes stratification or coating of water, which affects the mixing of seabed material and disturbs nutrition distribution (Li et al., 2020). However, the temperature is also needed in oxygen mixing from the surface to the deep waters (Lobine et al., 2021). Seawater temperature also affects surface currents, the distribution of plankton, and the survival of marine life to control the condition of aquatic ecosystems.

An increase in water temperature affects the metabolism and respiration of aquatic organisms and further increases oxygen consumption (Nie et al., 2017; Bonachea, 2021). An increase in water temperature of $10 \mathrm{C}$ causes an increase in oxygen consumption by aquatic organisms about 2-3 times. However, an increase in temperature accompanied by a decrease in dissolved oxygen levels is often unable to meet the oxygen needs of aquatic organisms to carry out metabolism, thus it affects their growth (Nelson, 2016; van Rijn et al., 2017; Das et al., 2018; Audzijonyte et al., 2019). Physical conditions may affect the chemical requirements of pond waters. The analysis of chemical parameters shows that in addition to natural physical factors, anthropogenic activities also cause chemical conditions between pond areas. The measurement results show varying values (Table 3 ) and uneven distribution for each physical and chemical parameter (Figure 4 \& 5) at each observation station. 
Table 3. Recapitulation of Water Suitability Parameter Data (Site Capability) at Each Observation Station

\begin{tabular}{lcccccccccc}
\hline \multirow{2}{*}{ Parameter } & \multicolumn{10}{c}{ Station } \\
\cline { 2 - 11 } & $\mathbf{1}$ & $\mathbf{2}$ & $\mathbf{3}$ & $\mathbf{4}$ & $\mathbf{5}$ & $\mathbf{6}$ & $\mathbf{7}$ & $\mathbf{8}$ & $\mathbf{9}$ & $\mathbf{1 0}$ \\
\hline Seawater depth (m) & 4.00 & 4.00 & 4.00 & 4.00 & 4.00 & 4.00 & 5.00 & 5.00 & 6.00 & 4.00 \\
Light Penetration (cm) & 80,50 & 70.00 & 89.00 & 81.30 & 78,50 & 79,50 & 98,5 & 91,50 & 14,12 & 13,45 \\
Turbidity (NTU) & 3.15 & 3.26 & 2.58 & 3.51 & 3.26 & 2.96 & 2.97 & 2.68 & 2.38 & 1.66 \\
Water current (m/s) & 25.00 & 20.00 & 23.00 & 25.00 & 10.00 & 10.00 & 12.00 & 27.00 & 10.00 & 23.00 \\
Temperature (C) & 31.00 & 34.00 & 32.00 & 32.00 & 33.00 & 33.00 & 32.00 & 34.00 & 37.00 & 34.00 \\
DO (mg/l) & 6.40 & 5.44 & 6.00 & 5.84 & 6.32 & 5.68 & 6.16 & 6.00 & 5.92 & 6.24 \\
pH & 6.50 & 6.80 & 6.40 & 6.90 & 7.30 & 7.10 & 7.10 & 7.20 & 7.30 & 7.50 \\
Salinity (\%) & 30.00 & 31.00 & 32.00 & 32.00 & 32.00 & 32.00 & 33.00 & 34.00 & 34.00 & 33.00 \\
Nitrate (mg/L) & 0.68 & 0.57 & 0.62 & 0.55 & 0.45 & 0.46 & 0.90 & 0.94 & 0.40 & 0.68 \\
Nitrite (mg/L) & 0.03 & 0.04 & 0.06 & 0.04 & 0.02 & 0.02 & 0.01 & 0.01 & 0.01 & 0.01 \\
Phosphate (mg/L) & 0.99 & 0.41 & 0.26 & 0.27 & 0.11 & 0.20 & 0.07 & 0.08 & 0.06 & 0.08 \\
Ammonia (mg/L) & 1.57 & 1.40 & 1.54 & 1.57 & 0.92 & 0.36 & 0.29 & 0.16 & 0.07 & 0.30 \\
BOD (mg/L) & 124.70 & 249.40 & 364.50 & 306.90 & 326.10 & 306.90 & 345.30 & 287.80 & 268.60 & 364.50 \\
Seabed materials & $\mathrm{S}$ & $\mathrm{S}$ & $\mathrm{S}$-Cs & Gs-Cs & Gs & S-Cs & S & S-Cs & S & GS \\
\hline Note: Cs = clam shell shards; Gs $=$ Grit-silt (muddy); and S $=$ Silt & & & & &
\end{tabular}

Figure 5 shows the condition of chemical factors in Tanjung Mas. Many chemical factors in the KJT aquatic environment are suitable for milkfish growth. Furthermore, dissolved oxygen (DO) levels meet seawater quality standards and support the development of cultured fish. Adequate dissolved oxygen
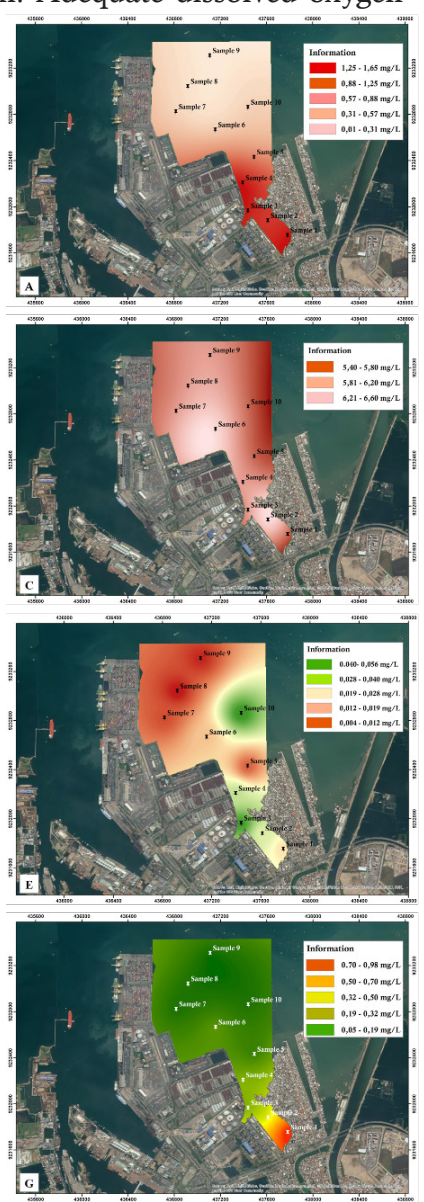

levels may be produced from plankton photosynthesis and air diffusion (Horak et al., 2018). In addition, oxygen is a limiting factor for water quality because it plays an essential role in the fermentation of organic and inorganic materials at the seabed (Orsi, 2018).
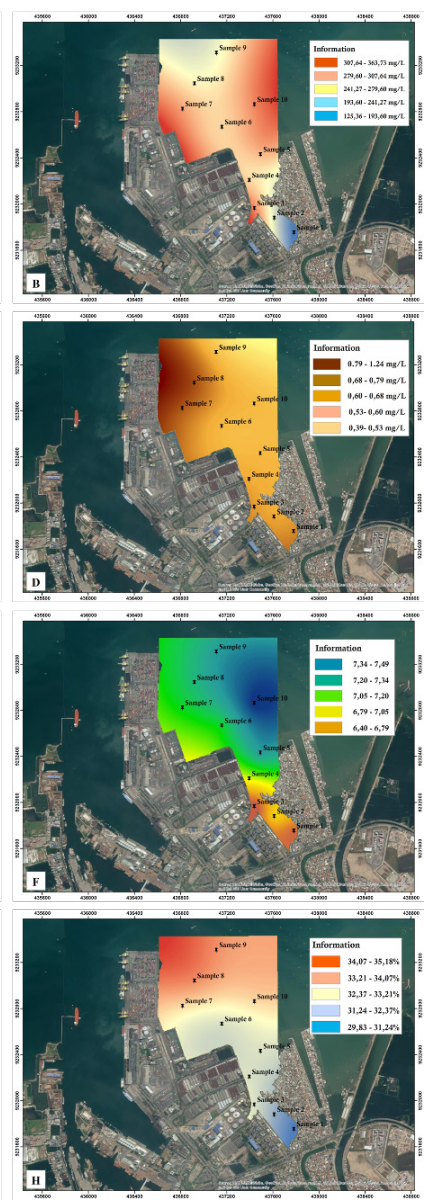

Figure 5. Chemical Factors Condition of the Research Site in Tanjung Mas: A) ammonia distribution; B) BOD level; C) DO; D) nitrate; E) nitrite; F) pH; G) phosphate; H) salinity of Tanjung Mas Fishpond Areas 
The needed $\mathrm{O}_{2}$ for decomposition and fermentation can be identified from biochemical oxygen demand (BOD) content. A higher concentration in the fishpond indicates the possibility of high organic matter in the waters (Jorgensen \& Marshall, 2016). The results of BOD measurements at ten observation stations show a value of $124.7 \mathrm{mg} / \mathrm{L}-364.5 \mathrm{mg} / \mathrm{L}$, especially at stations $3-9$. Based on the BOD criteria, the seawaters around Tanjung Mas are classified as high polluted by organic compounds. It is probably caused by the decomposition process of milkfish feed, which is sedimented at the seabed. In addition, the map (Figure 4B) shows that high BOD concentrations are distributed mainly near the industrial outfall areas even though the $\mathrm{pH}$ around the Tanjung Mas water area is in the neutral range of $6-7$ and supports milkfish cultivation. In nature, the $\mathrm{pH}$ value ranges from $4-9$, where the unbalancing of the $\mathrm{pH}$ affects aquaculture fish or the presence of seawater organisms.

The fermentation process of organic materials releases $\mathrm{N}$ into seawaters in the form of nitrate $\left(\mathrm{NO}_{3}\right)$, nitrite $\left(\mathrm{NO}_{2}\right)$, and ammonia $\left(\mathrm{NH}_{4}\right)$ (Oshiki et al., 2016; Spataru, 2017, 2021). The concentration of $\mathrm{NO}_{3}$ in Tanjung Mas ranges from $0.3947 \mathrm{mg} / \mathrm{L}-0.9386 \mathrm{mg} / \mathrm{L}$, while nitrite $0.0058 \mathrm{mg} / \mathrm{L}-0.0338 \mathrm{mg} / \mathrm{L}$, and ammonia $0.073 \mathrm{mg} / \mathrm{L}-1.568 \mathrm{mg} / \mathrm{L}$. High concentrations of $\mathrm{NO}_{3}$ and $\mathrm{NO}_{2}$ in the seawaters can stimulate the growth and development of phytoplankton and become an indicator of fishpond fertility (Hardikar et al., 2019). $\mathrm{NO}_{2}$ is also an indicator of decreasing $\mathrm{N}$ contamination because its formation comes from the oxidation of $\mathrm{NH}_{4}$ which is toxic. Then, an availability of $\mathrm{NO}_{2}$ comes from the oxidation of $\mathrm{NH}_{4}$ to $\mathrm{NO}_{2}$ carried out by Nitrosomonas bacteria, while the oxidation of $\mathrm{NO}_{2}$ to $\mathrm{NO}_{3}$ is carried out by Nitrobacter (Santoro et al., 2021). $\mathrm{NO}_{2}$ is usually found in lower amounts than $\mathrm{NO}_{3}$ because it is unstable and easily reacts with oxygen. The findings obtained in this study show that the measured $\mathrm{NH}_{4}$ levels are quite high at seven observation stations (stations 1, 2, 3, 4, 5,6 , and 10). The location is at the Mati River, which carries domestic waste from settlements. Organic materials from domestic waste increase the rate of decomposition and fermentation of organic materials to produce $\mathrm{NH}_{4}$ as a by-product. The increase in $\mathrm{NH}_{4}$ contamination is positively correlated with anthropogenic factors, primarily related to the residential, agricultural, livestock, and industrial sectors (Bessa et al., 2021; Sproson et al., 2021). In addition, the problem faced in the Tanjung Mas water area is the lack of suitable sanitation, which causes pollution and the balance of the pond waters ecosystem. Low $\mathrm{NH}_{4}$ concentrations were measured at stations 7,8 , and 9 because they are located far from settlements and industrial outfall, have more than $5 \mathrm{~m}$ depth, and are near the open sea. This condition improves water circulation due to ocean currents and a more homogeneous seawater diffusion process.

Domestic waste may be one of the main factors that increase phosphate concentrations in the KJT water area. Various studies have shown that human activities, including household waste, have increased the concentration of contaminants in the oceans, such as nitrogen (Jickells et al., 2017), phosphate (Badawy et al., 2018; Thiombane et al., 2019), and heavy metals (Chu et al., 2019; Bessa et al., 2021). It is indicated by the distribution of phosphate levels at stations 1 to 5, which is higher than the other five observation stations. Phosphate is a nutrient that is a determining factor in phytoplankton in the sea and is usually found in the form of organic compounds (Bristow et al., 2017).

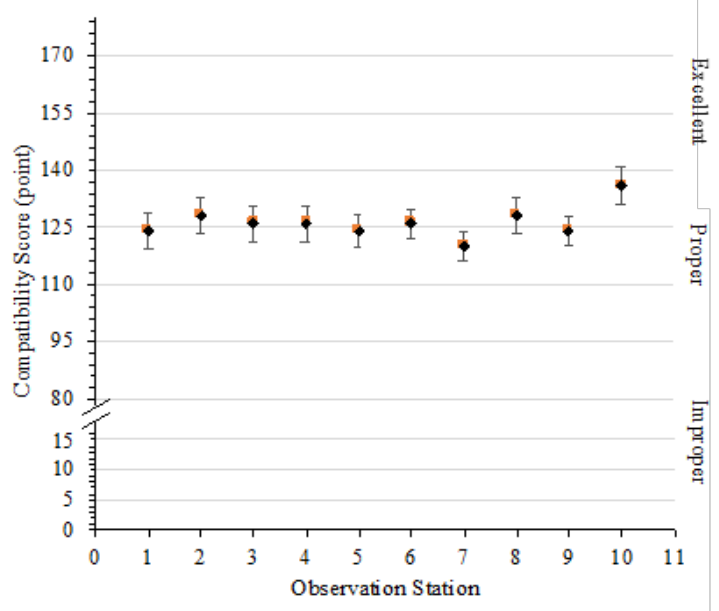

Figure 6. Compatibility for Milkfish Cultivation in Tanjung Mas Water Area Based on the Observation Station 
The water compatibility value (Figure 6) shows that all observation stations are categorized at the proper level (S2). It indicates that the Tanjung Mas water area is sufficient and can be developed as a KJT cultivation area. However, limiting factors require special attention to increasing milkfish productivity, such as $\mathrm{N}$ and $\mathrm{P}$ levels and BOD.

The total area of potential waters in the Tanjung Mas for KJT is $119.51 \mathrm{Ha}$, but referring to the government regulation, it is only $20 \%$ that can be used for aquaculture. Then the optimum area for the KJT aquaculture system that can be developed is only about 23,902 Ha. However, based on the observation, the existence of KJT has overcapacity. Twenty-two cages occupy it with more than $53.45 \mathrm{Ha}$ of water area. Furthermore, the utilization of the waters has exceeded the carrying capacity because the practical potential of the water area for the KJT system is only 2.4 cage/ Ha for only ten cage units. Therefore, it is necessary to reduce the number of KJT units by looking at the existing conditions.

High occupied water areas with dense cultured milkfish may overshoot the water's capacity and potentially trigger mass death of the marine organism. The condition of the waters directly adjacent to the sea provides an advantage for faster purification. However, the continuous input of domestic and industrial pollutants and low river discharge resulted in a low nature purification rate. It must be a common concern, considering that the waters in the KJT area are the output of several waste installations from the community (domestic) and industries.

Physiochemistry and KJT management in Tanjung Mas depicts new insight into milkfish cultivation in polluted areas. The study results show the potential of $\mathrm{KJT}$ as applicable aquaculture in the face of climate change. $\mathrm{KJT}$ is also superior to inland ponds because it can guarantee the circulation of physicochemical and nutrients to provide better opportunities for adaptation to climate change. $\mathrm{KJT}$ is an adaptive tool/effort for fish farmers to adapt the climate change which reduces their income. A main reason for using KJT in Tanjung Mas is more caused by large profits obtained from aquaculture using low-cost production. An interesting fact in this study also shows that the community does not yet have awareness about the implementation of sustainable milkfish cultivation by concerning the carrying capacity of the environment and product quality. In other words, economic reasons take precedence over health and environmental suitability to produce profitable cultivation commodities, even though, the KJT is contaminated by domestic and industrial waste. It needs an improvement of waste management system from industrial and household by providing sewage purification utilities and scheduling waste disposal based on tidal conditions after purification treatment.

\section{CONCLUSION}

In general, the physicochemical factors in Tanjung Mas water areas are proper and support milkfish cultivation. However, the existing condition shows that water utilization for milkfish aquaculture activities using KJT has exceeded the carrying capacity. It potentially disturbs milkfish growth and may lead to the unbalancing ecosystem and trigger the death of the marine organism. On the other hand, high pollution from industries and household waste has become a significant problem affecting milkfish growth and becoming a health issue. High $\mathrm{P}$ and $\mathrm{NH}_{4}$ are primarily detected in the observation station near the industrial outfall and the Mati River estuary, containing domestic waste.

\section{ACKNOWLEDGMENTS}

The acknowledgment is delivered to the Ministry of Education, Culture, and Higher Education for funding the research through the Penelitian Terapan Unggulan Perguruan Tinggi (PTUPT) Scheme, grant number: 43.14.7/ UN37/PPK.6.8/2021. Hopefully, the research results can be helpful for the improvement of coastal area management.

\section{REFERENCES}

Ahmed, N., Thompson, S., \& Glaser, M. (2019). Global Aquaculture Productivity, Environmental Sustainability, and Climate Change Adaptability. Environmental Management, 63(2), 159-172.

Andreas, H., Abidin, H. Z., Sarsito, D. A., \& Pradipta, D. (2018). Adaptation of Early Climate Change Disaster' to the Northern Coast of Java Island Indonesia. Engineering Journal, 22(3), 207-219.

Astuti, L. P., \& Warsa, A. (2020, July). Survival rate and growth rate of milkfish (Chanos chanos, Forsskal 1775) seeds in the acclimatization process at Ir. H. Djuanda Reservoir. In IOP Conference Series: Earth and Environmental Science (Vol. 535, No. 1, p. 012046). IOP Publishing.

Audzijonyte, A., Barneche, D. R., Baudron, A. R., Belmaker, J., Clark, T. D., Marshall, C. T., Morrongiello, J. R., \& van Rijn, I. (2019). Is Oxygen Limitation in Warming Waters a Valid Mechanism to Explain Decreased Body Sizes in Aquatic Ectotherms? Global Ecology and Bio- 
geography, 28(2), 64-77.

Badawy, W. M., El-Taher, A., Frontasyeva, M. V., Madkour, H. A., \& Khater, A. E. M. (2018). Assessment of Anthropogenic and Geogenic Impacts on Marine Sediments along The Coastal Areas of Egyptian Red Sea. Applied Radiation and Isotopes, 140(7), 314-326.

Bessa, A. Z. E., Ngueutchoua, G., Kwewouo Janpou, A., El-Amier, Y. A., Njike Njome Mbella Nguetnga, O. A., Kankeu Kayou, U. R., Bisse, S. B., Ngo Mapuna, E. C., \& Armstrong-Altrin, J. S. (2021). Heavy Metal Contamination and Its Ecological Risks in The Beach Sediments along The Atlantic Ocean (Limbe Coastal Fringes, Cameroon). Earth Systems and Environment, 5(2), 433-444.

Bonachea, L. A. (2021). A Low-Cost Laboratory Demonstration of The Effects of Temperature on The Metabolism of An Aquatic Poikilotherm. Journal of Biological Education, 55(1), 60-65.

Bosma, R. H., Hakim, L. L., \& Groeneveld, R. A. (2017). Investing in Climate Change Mitigation and Adaptation on Mangrove and Aquaculture Doubles Benefits. in Prociding The 3rd International Conference on Tropical and Coastal Region Eco-Development (ICTCRED 2017). Yogyakart, 2-4 October 2017.

Boyd, C. E., D'Abramo, L. R., Glencross, B. D., Huyben, D. C., Juarez, L. M., Lockwood, G. S., McNevin, A. A., Tacon, A. G. J., Teletchea, F., Tomasso, J. R., Tucker, C. S., \& Valenti, W. C. (2020). Achieving Sustainable Aquaculture: Historical and Current Perspectives and Future Needs and Challenges. Journal of the World Aquaculture Society, 51(3), 578-633.

BPS, B. P. S. (2021). Produksi dan Nilai Produksi Perikanan Budidaya Menurut Kabupaten/Kota dan Komoditas Utama di Provinsi Jawa Tengah, 2019. Online at https://jateng.bps.go.id/ statictable/2021/04/12/2366/produksi-dannilai-produksi-perikanan-budidaya-menurutkabupaten-kota-dan-komoditas-utama-diprovinsi-jawa-tengah-2019.html. [Accesed in September $\left.26^{\text {th }}, 2021\right]$.

Bristow, L. A., Mohr, W., Ahmerkamp, S., \& Kuypers, M. M. M. (2017). Nutrients that Limit Growth in The Ocean. Current Biology, 27(11), r474r478.

Cha, B. J., \& Lee, G. H. (2018). Performance of a Model Fish Cage with Copper-Alloy Net in a Circulating Water Channel and Wave Tank. Ocean Engineering, 151, 290-297.

Chang, B. V., Chang, Y. T., Chao, W. L., Yeh, S. L., Kuo, D. L., \& Yang, C. W. (2019). Effects of Sulfamethoxazole and Sulfamethoxazole-Degrading Bacteria on Water Quality and Microbial Communities in Milkfish Ponds. Environmental Pollution, 252, 305-316.

Chu, Z., Yang, Z., Wang, Y., Sun, L., Yang, W., Yang, L., \& Gao, Y. (2019). Assessment of Heavy Metal Contamination from Penguins and An- thropogenic Activities on Fildes Peninsula and Ardley Island, Antarctic. Science of the Total Environment, 646, 951-957.

Cornejo, P., Guerrero, N. M., Montes, R. M., Quiñones, R. A., \& Sepúlveda, H. H. (2020). Hydrodynamic Effect of Biofouling in Fish Cage Aquaculture Netting. Aquaculture, 526, 735367.

Das, S. K., Noor, N. M., Kai, K. S., Juan, Q. Z., Iskandar, N. S. M, \& De, M. (2018). Effects of Temperature on the Growth, Gastric Emptying Time, and Oxygen Consumption Rate of Mahseer (Tor tambroides) under Laboratory Conditions. Aquaculture Reports, 12(8), 20-24.

Failaman, A. N., Traifalgar, R. F. M., \& Corre, V. L. (2021). Survival of Nursery-Reared Juvenile Milkfish, Chanos chanos, at Different Transport Density and Temperature. Journal of Applied Aquaculture, 34(1), 1-15.

Ganesh, G., Devi, B. C., Reddy, D., Rao, A. S., Mohan, R. R., Pamanna, D., Kumar, P. R., \& Mahesh, L. N. (2020). Evaluation of Water Quality Parameters in Grow Out Phase of Brackish Water Fish Chanos Chanos (Milk Fish) in Floating Net Cages. Journal of Entomology and Zoology Studies, 8(5), 460-464.

Gusmawati, N., Soulard, B., Selmaoui-Folcher, N., Proisy, C., Mustafa, A., Le Gendre, R., Laugier, T., \& Lemonnier, H. (2018). Surveying Shrimp Aquaculture Pond Activity using Multitemporal VHSR Satellite Images - Case Study from the Perancak estuary, Bali, Indonesia. $M a$ rine Pollution Bulletin, 131(6), 49-60.

Hamzah, F., Agustiadi, T., Susanto, R. D., Wei, Z., Guo, L., Cao, Z., \& Dai, M. (2020). Dynamics of the Carbonate System in the Western Indonesian Seas During the Southeast Monsoon. Journal of Geophysical Research: Oceans, 125(1), $1-45$

Hanke, I., Ampe, B., Kunzmann, A., Gärdes, A., \& Aerts, J. (2019). Thermal Stress Response of Juvenile Milkfish (Chanos chanos) Quantified by Ontogenetic and Regenerated Scale Cortisol. Aquaculture, 500(9), 24-30.

Hardikar, R., Haridevi, C. K., Ram, A., Khandeparker, R., Amberkar, U., \& Chauhan, M. (2019). Inter-annual Variability of Phytoplankton Assemblage and Tetraspora gelatinosa Bloom from Anthropogenically Affected Harbour, Veraval, India. Environmental Monitoring and Assessment, 191(2), 87-104.

Henriksson, P. J. G., Banks, L. K., Suri, S. K., Pratiwi, T. Y., Fatan, N. A., \& Troell, M. (2019). Indonesian Aquaculture Futures-Identifying Interventions for Reducing Environmental Impacts. Environmental Research Letters, 14(12), 124062

Horak, R. E. A., Qin, W., Bertagnolli, A. D., Nelson, A., Heal, K. R., Han, H., Heller, M., Schauer, A. J., Jeffrey, W. H., Armbrust, E. V., Moffett, J. W., Ingalls, A. E., Stahl, D. A., \& Devol, A. H. (2018). Relative Impacts of Light, Temperature, and Reactive Oxygen on Thaumarchaeal 
Ammonia Oxidation in the North Pacific Ocean. Limnology and Oceanography, 63(2), 741-757.

Hu, S., Zhang, Y., Feng, M., Du, Y., Sprintall, J., Wang, F., Hu, D., Xie, Q., \& Chai, F. (2019). Interannual to Decadal Variability of UpperOcean Salinity in The Southern Indian Ocean and The Role of The Indonesian Throughflow. Journal of Climate, 32(19), 6403-6421.

Hukom, V., Nielsen, R., Asmild, M., \& Nielsen, M. (2020). Do Aquaculture Farmers Have an Incentive to Maintain Good Water Quality? The Case of Small-Scale Shrimp Farming in Indonesia. Ecological Economics, 176(8), 106717.

Irsadi, A., Anggoro, S., Soeprobowati, T. R., Helmi, M., \& Khair, A. S. E. (2019). Shoreline and Mangrove Analysis Along Semarang-Demak, Indonesia for Sustainable Environmental Management. Jurnal Pendidikan Ipa Indonesia, 8(1), $1-11$.

Jickells, T. D., Buitenhuis, E., Altieri, K., Baker, A. R., Capone, D., Duce, R. A., Dentener, F., Fennel, K., Kanakidou, M., LaRoche, J., Lee, K., Liss, P., Middelburg, J. J., Moore, J. K., Okin, G. Oschlies, A., Sarin, M., Seitzinger, S., Sharples, J., Singh, A. Suntharalingam, P. Uematsu, M. Zamora, L. M. (2017). A Reevaluation of the Magnitude and Impacts of Anthropogenic Atmospheric Nitrogen Inputs on the Ocean. Global Biogeochemical Cycles, 31(2), 289-305.

Jorgensen, B. B., \& Marshall, I. P. G. (2016). Slow Microbial Life in the Seabed. Annual Review of Marine Science, 8(7), 311-332.

Kumar, D. G., Karthik, M., \& Rajakumar, R. (2017). Study of Seasonal Water Quality Assessment and Fish Pond Conservation in Thanjavur, Tamil Nadu, India. Journal of Entomology and Zoology Studies, 5(4), 1232-1238.

Li, G., Cheng, L., Zhu, J., Trenberth, K. E., Mann, M. E., \& Abraham, J. P. (2020). Increasing Ocean Stratification Over the Past Half-Century. $\mathrm{Na}$ ture Climate Change, 10(12), 1116-1123.

Lobine, D., Rengasamy, K. R. R., \& Mahomoodally, M. F. (2021). Functional Foods and Bioactive Ingredients Harnessed from the Ocean: Current Status and Future Perspectives. Critical Reviews in Food Science and Nutrition, 17(1), 1-30.

Mandal, B., Bera, A., Kailasam, M., Padiyar, A., Ambasankar, K., Alavandi, S. V., \& Vijayan, K. K. (2018). A Guide to Milkfish (Chanos chanos) Aquaculture. Central Institute of Brackishwater Aquaculture. Cennai, India. Central Institute of Brackishwater Aquaculture (ICAR).

Martuti, N. K. T., Pribadi, R., Dewi, N. K., Sidiq, W. A. B. N., \& Nugraha, S. B. (2020). The Dynamics of Coastline and Mangrove Ecosystems in Coastal Area of Mangkang Kulon Subdistrict, Semarang. In IOP Conference Series: Earth and Environmental Science (Vol. 550, No. 1, p. 012011). IOP Publishing.
Nelson, J. A. (2016). Oxygen Consumption Rate v. Rate of Energy Utilization of Fishes: a Comparison and Brief History of the Two Measurements. Journal of Fish Biology, 88(1), 10-25.

Nie, H., Chen, P., Huo, Z., Chen, Y., Hou, X., Yang, F., \& Yan, X. (2017). Effects of Temperature and Salinity on Oxygen Consumption and Ammonia Excretion in Different Colour Strains of The Manila Clam, Ruditapes philippinarum. Aquaculture Research, 48(6), 2778-2786.

Olatayo, A. A. (2014). Assessment of Physico-Chemical Parameters of Waters in Ilaje Local Government Area of Ondo State, Nigeria. International Journal of Fisheries and Aquatic Studies, 1(5), 84-92.

Orsi, W. D. (2018). Ecology and Evolution of Seafloor and Subseafloor Microbial Communities. $\mathrm{Na}$ ture Reviews Microbiology, 16(11), 671-683.

Oshiki, M., Satoh, H., \& Okabe, S. (2016). Ecology and Physiology of Anaerobic Ammonium Oxidizing Bacteria. Environmental Microbiology, 18(9), 2784-2796.

Proisy, C., Viennois, G., Sidik, F., Andayani, A., Enright, J. A., Guitet, S., Gusmawati, N., Lemonnier, H., Muthusankar, G., Olagoke, A., Prosperi, J., Rahmania, R., Ricout, A., Soulard, B., \& Suhardjono. (2018). Monitoring Mangrove Forests after Aquaculture Abandonment using Time Series of Very High Spatial Resolution Satellite Images: A Case Study from The Perancak Estuary, Bali, Indonesia. Marine Pollution Bulletin, 131, 61-71.

Purwaningsih, R., \& Hermawan, F. A. (2021, February). Risk analysis of milkfish supply chains in Semarang using house of risk approach to increase the supply chain resilience. In IOP Conference Series: Earth and Environmental Science (Vol. 649, No. 1, p. 012018). IOP Publishing.

Ratnawati, H. I., Aldrian, E., \& Soepardjo, A. H. (2018, October). Variability of evaporationprecipitation (EP) and sea surface salinity (SSS) over Indonesian maritime continent seas. In AIP Conference Proceedings (Vol. 2023, No. 1, p. 020252). AIP Publishing LLC.

Sambu, A. H. (2017). Utilization of Displaced Land of Former Red Stone Excavation for Milkfish Farming by Stick Net Cage System (A Case Study at Gentungan, Gowa Regency, South Sulawesi, Indonesia). Modern Applied Science, 11(7), 68-73.

Santoro, A. E., Buchwald, C., Knapp, A. N., Berelson, W. M., Capone, D. G., \& Casciotti, K. L. (2021). Nitrification and Nitrous Oxide Production in the Offshore Waters of the Eastern Tropical South Pacific. Global Biogeochemical Cycles, 35(2). e2020GB006716.

Spataru, P. (2021). Influence of Organic Ammonium Derivatives on the Equilibria Between of NH4 + , NO2- and NO3- Ions in River Waters. 1-24.

Spataru, P. (2017). Influences of Organic Ammonium 
Derivatives on the Change of Concentrations of Nh4+, No3 -, No3 - in River Water. in Proceeding International Symposium "The Environment and The Industry." Bucharest, 28-29 September 2017.

Sproson, A. D., Selby, D., Suzuki, K., Oda, T., \& Kuroda, J. (2021). Anthropogenic Osmium in Macroalgae from Tokyo Bay Reveals Widespread Contamination from Municipal Solid Waste. Environmental Science Technology, 54(15), 9356-9365.

Srithongouthai, S., \& Tada, K. (2017). Impacts of Organic Waste From a Yellowtail Cage Farm on Surface Sediment and Bottom Water in Shido Bay (the Seto Inland Sea, Japan). Aquaculture, 471(3), 140-145.
Surya, M. Y., He, Z., Xia, Y., \& Li, L. (2019). Impacts of Sea Level Rise And River Discharge on The Hydrodynamics Characteristics of Jakarta Bay (Indonesia). Water, 11(7). 1384-1402

Thiombane, M., Di Bonito, M., Albanese, S., Zuzolo, D., Lima, A., \& De Vivo, B. (2019). Geogenic Versus Anthropogenic Behaviour and Geochemical Footprint of $\mathrm{Al}, \mathrm{Na}, \mathrm{K}$ and $\mathrm{P}$ in the Campania Region (Southern Italy) soils Through Compositional Data Analysis and Enrichment Factor. Geoderma, 335(2), 12-26.

van Rijn, I., Buba, Y., DeLong, J., Kiflawi, M., \& Belmaker, J. (2017). Large But Uneven Reduction in Fish Size Across Species in Relation to Changing Sea Temperatures. Global Change Biology, 23(9), 3667-3674. 